\title{
Ethnic Conflicts and the Role of the Media: The Case of Turkish Media
}

\author{
Dr. H. Esra Arcan \\ Istanbul University, Turkey \\ arcan@istanbul.edu.tr
}

\section{Doi:10.5901/mjss.2013.v4n10p338}

\begin{abstract}
Since the World War II the history has showed us how media can be directly involved in ethnic conflicts. Sudan, Rwanda, Yugoslavia, UK-Northern Ireland, Spain, Chechnya, Sri Lanka, and Turkey are current examples of these conflicts. In Turkey, an armed conflict between the Turkish Armed Forces and the Kurdish armed organization PKK has caused mass human rights violations and loss of human lives and; strained the economy and damaged the environment. In this study, the following points are examined: 1) what are the connections between ethnic conflict and the media; 2) how do Turkish mainstream media framed the ethnic conflict; 3) what role do the media can play to prevent/resolve ethnic conflicts. The study also includes comparison of fundamental approaches of peace journalism and war journalism towards the conflict. Although most of the examples that shows what role the media played in ethnic conflicts are negative. The study concludes that the media can play an effective, positive role to prevent or reconcile ethnic conflicts and to contribute to the post conflict resolution, reconciliation and peace building.
\end{abstract}

Keywords: Turkish media, ethnic conflict, Kurdish question, media framing, peace building

\section{Introduction}

In the beginning of the 21st century, it appears that a much desired peaceful future is being overshadowed by armed conflicts. Today, peace is the ultimate goal for humanity. Hamelink (2008: 77) says that "A rough count would tell us that after the Second World War and the solemn pledge by the international community that it would not allow this barbarism to happen again, the world has known fewer than 40 days during which nowhere in the world was a war fought." Besides interstate wars, "Following the end of the Cold War, the number of violent internal conflicts went up sharply and new conflicts emerged at the global level." (Gilboa, 2009: 89) Not only underdeveloped countries also in developed and developing countries' peoples have suffered the internal conflicts such as; Britain, Spain, Turkey where ethnic armed conflict was occurred related to minority issues respectively Irish, Bask, and Kurdish question.

The role of the media was mentioned often before, during and post conflict processes but mostly studies focused on negative effects of the media and the capacity of the media for peace building remained unexplored and neglected. (Gilboa, 2009: 88; Laplante and Phenicie, 2009: 252; Wolsfeld quoted in Spencer, 2003: 56) However, the role of the media is so crucial that even "the presence of reporters on the ground in Bosnia in certain instances prevented or at least postponed atrocities" as Hawkins (2011: 63) cites from Botes.

Even if there is no study that assets, measures and proves impact of the media on ethnic conflict, yet in most of the cases the effect of the media on ethnic conflict is agreed and "There is an emerging belief that the media may well be the most effective means of conflict resolution and preventing new wars" (Howard, 2003:2) Therefore "Nearly all modern post-conflict peace-building efforts have included media programs" (Kalathil et al. 2008) According to Howard (2003:1) estimated 1 billion US dollars was invested in interventionsrelating to media in ten years. Some important efforts relating to media's conflict prevention, resolution, reconciliation or peace-building role is employed by UN in numerous conflicted areas.

\section{Relationship between Ethnic Conflicts and the Media: The Media as Warmonger}

The most drastic and well known examples of hate speech communicated through the media that have brought worldwide attention to the phenomenon experienced in Rwanda and Yugoslavia were both incited by media hate speech. Davison (2006: 50) suggests that the ability to successfully convey the politics of hate relates to a number of factors including media control for mass mobilization "Nazi and fascist parties took advantage of press laws, urbanization and 
mass communication to agitate and attract followers. Likewise, Milosevich in Serbia and the Hutu extremists in Rwanda established ultranationalist networks and controlled important media outlets." Genocide, brutal massacres, using rape as a tool of genocide was common features and results of ethnic violence in both Rwanda and Former Yugoslavia. In both countries the media played a negative role to escalate the conflict and served to murderers.

If we look at more closely what happened in Rwanda, we can see deadly consequences of wrong doings of Rwandan media. "The private broadcast company Libre des Mille Collines and the national Radio Rwanda took active roles in fomenting ethnic hatred among citizens driving the Hutu people to kill at least half million of the Tutsi population in 1994." (Laplante and Phenicie 2009)Even they broadcasted suggestions on how to kill Tutsis. "The ensuing conflagration resulted in the deaths of some 800 000Tutsis and moderate Hutus...Key to the brutal efficiency of the massacres were Rwanda's radio and newspapers. Rwandan newspapers published a "hit list" of targeted victims deemed unfaithful to the mores ofthe nation. Reportage from the national radio reinforced the perception that national security depended upon eliminating- rather, "exterminating" or cleaning out-not only the minority view but the minority members themselves" (Adrien and Mark;Wing and Jhonson; des Forges quoted in Bernard, 2009:190, 191). Because of such powerful effect of the media in conflicted areas UN is employing new media policy.

General Dallaire who was UN Commander in Rwanda during conflict, said simply jamming Hutu broadcasts and replacing them with messages of peace and reconciliation would have had a significant impact on the course of events (quoted in Metzel, 1997). The role of the media in escalating conflict and causing genocide in Rwanda is so clear that even it is approved by UN's tribunal verdicts. Court decision on genocidal role of the media in Rwanda declares that "mass media hate speech constitutes genocide, incitement to genocide and crimes against humanity" (Int'l Crim. Trib. For Rwanda trial Chamber I: Prosecuted v. Nahimana, Barayagwiza and Ngeze, (Media Case))

Link between the media and mass slaughters was also clear in Bosnian case. In the Republic of BosniaHerzegovina, conflict between the three main ethnic groups, the Serbs, Croats, and Muslims, resulted in genocide committed by the Serbs against the Muslims in Bosnia. As a result of conflict 200,000 Muslim civilians had been systematically murdered. More than 20,000 were missing and feared dead, while 2,000,000 had become refugees. It was, according to U.S. Assistant Secretary of State Richard Holbrooke, "the greatest failure of the West since the 1930s."Bennet who is director of International Crisis Group's Balkan Project explains how Serb nationalists harnessed the media to destroy Yugoslavia and stresses that "Media have arguably been the most destructive weapon in the wars of Yugoslav dissolution. Indeed it is said in the former Yugoslavia that all victims died twice: fist on television and then in reality...Myth, fantasy, half truths and brazen lies were packaged each night into the television news...Milosevich was able to beam his new Serb nationalism into every home in Serbia and beyond via saturation television...The allegations against anyone who dared to question Milosevich on any matter were ludicrous, yet by this time reality had gone out the window."As it was in the case of Rwanda, perpetrators of genocide in former Yugoslavia went before International Criminal Tribunal for the Former Yugoslavia (ICTY) and sentenced. In the ICTY one of the indictments against Serbian leader Milosevic was his use of the Serbian state-run media to create an atmosphere of fear and hatred among Yugoslavia's Orthodox Serbs by spreading "exaggerated and false messages of ethnically based attacks by Bosnian Muslims and Catholic Croats against the Serb people..."Milosevic succeeded this by centralizing Radio Television Belgrade, Radio Television Novi Sad and Radio Television Pristina and they became a part of Radio Television of Serbia. Besides that he controlled the independent media by creating shortages of paper, limiting their distribution, stopping supplies and equipment, imposing heavy fines and punishments. La Brosse (2003) reports all this details in his expert report that is compiled at the request of the Prosecutor of the ICTY.

\section{Information Intervention: Jamming Genocide}

In view of these considerations, international-intergovernmental organizations employed "information intervention" methods in order to end ethnic conflicts. Although information intervention methods are criticized from freedom of press point of view, yet warning of General Dellaire should be kept in mind; simply jamming Hutu broadcasts and replacing them with messages of peace and reconciliation would have had a significant impact on the course of events. (Metzl, 1997: 1) Moreover it is suggested that UN should establish an independent information intervention unit with three primary areas of responsibility: monitoring, peace broadcasting, and in extreme cases, jamming radio and television broadcast. (Metzl, 1997: 2) Also Hamelink (2008: 82) stressed on monitoring media for detecting early warning and suggested that an international media alert system is needed to monitor media contents in conflicted societies.

NATO's more aggressive responses are still in minds. In Bosnia, against Serb Radio Television's biased and distorted news NATO troops seized one of the station's transmission relay towers and held it for five days until "Serb 
hard-liners agreed not to air "inflammatory" anti-NATO broadcasts and set aside one prime time hour a day for programs expressing "other political views". At the same time, the north Atlantic Council authorized NATO peacekeepers in Bosnia to take all actions necessary to "suspend or curtail programming that is hostile to the spirit of the Dayton peace accord. (Metzel, 1997:2) Moreover, in Kosovo war NATO fired on the TV building in Belgrade and justified by that "Serbian TV was a legitimate target because it was spreading propaganda that incited hatred of Kosovo Albanians. Later justification was changed: suspicious military signals had been detected from the building." Another example that shows war is fought in the media as well as battlefield is from Kabul. Same justification was used by American troops in Afghanistan. "When Kabul was taken, an American missile completely destroyed al-Jazeera's editorial office" (Nohrstedt, 2009: 109) that was the only Arab TV station to report war victims. Because of these incidents media interventions are debatable and get criticism as well as praise. On one hand, in defense of human rights "jamming genocide" is sometime necessary; on the other hand, there is abusive use of it, especially in asymmetric wars.

\section{Covering and Broadcasting Peace: The Media as Peace Maker}

It is thru that the media single-handedly cannot start a war; it is also thru that the media single-handedly cannot end conflict. Nevertheless there have been an increasing number of successful "information interventions" in recent years. UN or NGOs' radio stations and programs in peace missions in several countries have disseminated impartial, reliable news and information and developed conflict resolution strategies. Recently media and peace building efforts has become integrated into the humanitarian aid and intervention policies by EU, UN, the World Bank and donors like US, international NGOs and foundations and a survey, that was by no means a complete, shows in mid 2002, 115 million Euros budgeted for projects related to media and peace-building. (Howard, 2003: 8-9) Media interventions for peacebuilding have focused on training journalists on human rights reporting and conflict analysis and content production as news, dramas, documentaries, children programs, etc. most of that address the roots of conflicts.

In last decades sufficient evidence has been accumulated to justify the role of media on resolution, reconciliation, and peace-building and peace development in conflicted areas from Europe to Africa, from Asia to America which has proved media can play a role as peace makers even peace. Harnessing words against wars can create a new peace forces. Some examples can explain the constructive role of the media and communication.

Several peace oriented media projects served to resolution, reconciliation, and peace-building. Rwanda, Burundi, Democratic Republic of Congo and former Yugoslavia where the cruelest conflicts occurred, some of the most effective media projects applied. La Benevolencija, UNHCR information campaign, Radio UNMIR, Studio ljambo, Radio Agatashya, Radio Okapi, Radio Isanganiro, The Hirondelle News Agency in Rwanda, Burundi, Democratic Republic of Congo and TV Open Broadcast Network, Radio FERN, Project SPEAR, Peace agreement media campaign, Radio Blue Sky broadcasted several campaigns, dramas, programs to promote peace in former Yugoslavia. Beside that examples there are more media projects in Africa such as; Search for Common Ground Studio (Angola), Radio MINURCA, Radio Ndeke Luka (Central African Republic), STAR Radio, Talking Drum Studio, TRC of Liberia, Moses (Liberia), Radio Soap Opera (Senegal-Casamance region), Talking Drum Studio, UNHCR Campaign (Sierra Leone), Radio Voice Hope, Gurtang Peace Media Project (Sudan), Peace Media and Counterterrorism Project of Center for Global Peace (Uganda).

Also in Asia and America we can see useful and effective peace oriented projects such as; International Organization of Migration Media Program (Afghanistan), Radio UNTAC (Cambodia), Studio Moris Hamutuk, Geng Bola Gembira comic book (Indonesia/East Timor), Medios par la Paz (Colombia). Media projects that are harnessed to reconciliation Israel-Palestine conflict are also remarkable such as; Voice of Peace Radio, The Common Ground News Service, RAM FM, Radio all for Peace, Sesame Street program.

Before, during and after a conflict to form peace oriented media is a useful and effective tool to stop conflict and promote peaceful communication, but the most important approach is to establish the media that is respectful to the journalism and broadcasting ethic codes and principally aim to play a constructive role to provide social peace. In Europe the role of the media during the peace process of Northern Ireland is one of constructive example.

A journalist states "I think it is fair to say that there would have been no Good Friday Agreement without the media. There was simply no forum to get this thing started except through the news." (Spencer quoted in Reuben, 2009:59) As it is reminded "It is important to educate the public about the sources of conflict and the potential for violence or conflict resolution."(Gilboa, 2009:106), thus in Britain "by promoting political contestations between parties, carrying dialogue and mediating between oppositional parties, television news became a significant influence on the field within which those contestations took place and in so doing, took on a participatory role within the politics of peace." (Spencer, 2003:59) 


\section{The Kurdish Question of Turkey and the Conflict in a Historical Context}

Kurds and Turks have a long common history as citizens of the Ottoman Empire. Since a large part of the Middle East was part of the Ottoman Empire, Kurds used to live under the Ottoman rule and had autonomy in their quasi-independent tributary provinces. Today, Kurdish citizens of Turkey constitute a large ethnic and linguistic group and around 15 million of the country's citizens identify themselves as Kurds and speak Kurdish. (Tarhan, 2013) The Kurds have been subject to systematic state oppression and denial of their ethnic identity since the creation of the Turkish Republic in 1923. (Özkırımlı, 2013: 28)

As it was same all around the world, 1960s and 1970s was the time of political struggles. TheCivil Rights Movement in North America, Marxist-Leftist movements in Latin America and Europe was dominating youth and the working class. The political atmosphere was not any different in Turkey. The leftist youth and workers movement was rising. In this climate, some Kurdish political activists split from the Turkish socialist movement under the leadership of Abdullah Öcalan to form the Partia Karkeren Kurdistan (the Kurdistan Workers' Party) or PKK. The PKK made its first appearance in 1974 (Laciner and Bal, 2004) In 1980, the Turkish Military, in order to eradicate leftist opposition, seized power and stayed until 1983. Mass human rights violations and severe oppression occurred across the board regardless of ethnic background.

In 1984, under these circumstances PKK started an armed struggle against the Turkish Army.Turkish authorities have treated this conflict as a security problem and a terrorist act and thus, the prevention of this conflict was considered in the context of war against terrorism In 1999, seizure of Abdullah Öcalan by the Turkish government did not improve the situation.

Since 1984, the violent conflict has been continuing for 29 years but the framing the issue as terrorism did not bring any solutions. During this time, more than 40000 people died and around 6000 persons became victim of extra judicial execution. In 1990s, according to the official Turkish sources, 820 villages and 2,345 smaller settlements were depopulated. However, according to Diyarbakir Bar Association 3000 villages were depopulated and 2 million people were internally displaced. Also, according to the government sources, $50 \%$ of the displaced people have already returned to their home but these figures are found unreliable by the Human Rights Watch in their report.

\section{Armed Conflict and the Media in Turkey}

"Any examination of contemporary Turkish State Discoursediscloses that the Turkish state has, for a long time, consistently avoided recognizing the Kurdishness of the Kurdish question. This is hardly surprising, since the republican Turkish state denied that the Kurds existed. From the mid 1920's until the end of the 1980's, the Turkish state 'assumed' that there was no Kurdish element on Turkish territory" says Yeğen (1999:555) "The majority of Turkish citizens and institutions have in past decades considered the "Kurdish Question" as only a terrorism issue, in which the "answer" to the "question" was to be found in the successful elimination of the separatist terrorist organization, the Kurdish Workers Party (PKK)." (Aydınlı and Özcan, 2011: 441) Turkish media acted in same way and denied existence of Kurds and the Kurdish question and rather than the constructive language the media preferred to employ destructive approach. Instead of taking side human rights and peace the media took side with war. It can be seen in the study of Somer (2005: 591) "in 1984 and 1985, the mainstream Turkish daily Hürriyet published only 25 articles that were fully or partially related to the country's ethnic Kurds. Only 3 of these 25 articles used the word Kurd in reference to a person, group, concept, or place. In those days, the media rarely covered issues related to Kurds and, when they did, did not use the word Kurds."

As it is stated by Wolfsfeld ${ }^{1}$ the discourse of the media is determined by political elites and politics almost always comes first. The media do not initiate but follow or "reflect changes in the political environment because news stories are, for the most part, reactive...As Schudson puts it news "does not constitute political discourse but relays, refines, and reuses it". (Wolsfeld, 2010: 30) Accordingly, as a result of changed political climate in Turkish media the discourse has changed and "in the first 5 months of 2003 alone, Hürriyet published a total of 114 articles related to Kurds within Turkey; 47 of those made a reference to Kurdishness as a group identity at least once by using terms such as Kurds, ethnic Kurds, or Turkish citizens of Kurdish origin." (Somer, 2005: 591,592) Although by time the media have made references Kurdishness and used the words like Kurd or Kurdish, unfortunately most of time news employed hate speech related to Kurds. According to Hrant Dink Foundation Hate Speech Media Monitoring Report (January-April 2011, p: 5, 6), Kurds are one of the most targeted group by the Turkish media that employ hate speech against them. Hate speech against

${ }^{1}$ GadiWolfsfeld, (undated article) The Role of the News Media in ConflictandPeace: towords a more General Theory, available online at: htpp://politics.huji.ac.il/gadiwolfsfeld/pdf 
Kurds are produced in various ways in news, mostly words or stereotypes like blood thirsty-sanguinary, invader, separatist were used to define them.

East Anatolia wisepeople committee member Sibel Eraslan expressed emotional burden of being a member of the committee in an interview on TV2 and stated that since East Anatolia is one of the most affected two regions by armed conflict's human rights violations, she heard the most dramatic stories that region's people experienced and it was so difficult to deal with such emotional burden. She pointed out also that "I was not prepared to hear such dramatic stories because I had not read news about all this realities in the media. The media did not cover most of what happened to the Kurds. We Westerners of Turkey do not know what happened during the armed conflict to the Easterners of Turkey." Eraslan is not an ordinary citizen she is a former president of woman branch of Refah Party which government party is successor of, so she is politically quite active person. Also she is a story writer and a very well known newspaper columnist of Islamic milieu with a distinctive feminist approach. Therefore her sincere confession is an important indicator that proves even a columnist and politically active person can be deprived to know the truth about what is going on in her/his country because of the silence or ideologically biased coverage of the media. Thus the question of Reuben (2009:47) gains a special importance; "Under what conditions does the news media's coverage of conflict lead to constructive or destructive outcomes?" It is obvious that mainstream news media in Turkey did not covered the Kurdish Question objectively if they ever did their coverage was biased and echoed the voice of state's dominant ideology that favors militaristic approach which was an example of destructive media outcome. This is the characteristic of war journalism which "War journalism is driven by propaganda and manipulation and is therefore biased and distorted." (Galtung quoted in Gilboa, 2009: 101) This type of media outcomes polarize people, escalate conflict, otherize distinct group (s) of society as 'them' and dehumanize, demonize the 'other' easily. As a result of it even if national or international human rights organizations try to give voice to the truth, people become deaf and blind just as media is and it changes when elites especially political elites changed their attitude toward the question.

Although since 1991 governments has declared their 'recognition the Kurdish reality' but it never turned to a resolution or peace process because of the dominant nationalist and pro militarist political climate.Recently, after eradicating dominance of military forces over civil politics,Turkish society is experiencing a difficult transformation process that also presents opportunities for democratization. In mid 2009 pro Islam AKP (Justice and Development Party) government launched a 'Kurdish Opening'(it is also addressed as Kurdish opening, democratization opening, resolution process, peace process etc.)that was the boldest attempt ever made by a Turkish government to reach the resolution to the Kurdish question. Even if the process is interrupted more than once, finally Erdoğan's government started negotiations with PKK to end armed conflict and to solve the Kurdish question by democratic reforms at the beginning of 2013.Therefore it is crucial to understand the role of the media that if whether it serves to democratization and social resolution or fuels conflict. Thus the study focuses on the attempts by the Erdoğan's government to promote the peace process and its reflection on the Turkish news media.

In order to promote the peace process and to get accustomed public to talk about solving Kurdish question,the government established a wisepeople committee for geographically seven different regions of Turkey that are Marmara, Aegean, Mediterranean, Black Sea regions and Central, North Eastern and South Eastern Anatolia regions. (Kurds are intensively live in respectively South East and North East shortly called East that connotes Kurdish area. For a long time 'Question of East' referred to the'Kurdish Question') Total of 63 persons who are academics, writers, actors, singers organized meetings within their regions' people who are pro and con for peace process, NGOs, and visited special groups who are specially affected by arm conflict such as families of soldiers and forcibly disappeared or extra judicially executed persons who died during conflict. During this meetings, groups that are against and for peace process first time gathered together to discuss the issue, in doing so they talked to each other face to face and listened each other's opinions and stories first time. At the end of the almost three months the wisepeople committee that includes public figures and celebrities reported, peoples' demands, concerns, warnings, suggestions and opinions related to peace process to the Prime Minister of Turkey Recep Tayyip Erdoğan in a meeting on 26 June 2013.

\section{Scope and Method of the Study}

In this study, two Turkish newspapers, nationalist Sözcü and left-liberal Radikal will be examined and compared related to how they approached, framed the wisepeople committee's efforts and peace process, and what kind of discourse they employed in their news. Therefore the scope of the study includes news related to wisepeople committee's activities

224 National TV Channel, Moderatör Gece Haber (Moderator Night News), 26062013 at:11 pm 
which were realized between 3 April and 26 June 2013 in Sözcü and Radikal newspapers. Two newspapers are chosen according to their different ideological and political attachments. Sözcü newspaper is known as secularist, republican, nationalist and pro status quo as a result against peace process. Radikal newspaper is known as left-liberal and against status quo as a result pro peace process.

\section{Findings}

\subsection{Peace OrientedFraming and War Oriented Framing of the Conflict}

Pauly (2009: 7) asks "Is journalism interested in resolution or only in conflict" which is a fair and important dilemma for journalists and the media organizations that must be questioned. What the media is interested in can be examined by framing analysis of the news. According to Entman (1993:5) framing is "to select some aspects of a perceived reality and make them more salient in a communicating text, in such a way as to promote a particular problem definition, causal interpretation, moral evolution, and/or treatment recommendation for the item described." Also Gamson and Modigliani (1989: 3) stress that framing is "central organizing idea...for making sense of relevant events, suggesting what is at issue." In our case two oppositeframing are dominant as peace/conflict oriented framing of news in Radikal and war/violence oriented framing of news in Sözcü. Newspapers respectively show the characteristics of peace/conflict journalism and war/violence journalism. ${ }^{3}$

As it is explained by Galtung, McCormick and Lynch and others Peace/conflictJournalism is peace/conflict oriented, truth oriented, people oriented, and solution oriented while war/violence journalism is war/violence oriented, propaganda oriented, elite oriented and victory oriented. According to these fundamental features, news in Radikal and Sözcü takes opposite positions that can be seen in the headlines of news, such as:

"An honorable peace for both two parties"17 04 2013; "I have been started the peace process by getting married with a Kurd." 3105 2013; "Altan Tan: West worries about division of country, East worries about to be deceived" Radikal framed the peace process as win- win situation for both parties. However Sözcü suggested zero-sum situation in favor of security forces in its headlines such as:

"Actors, apostates, separatists: Bahçeli: 63 dark faces will tell you with enthusiasm how Turkey will be divided" 05 04 2013; "A veteran soldier threw his prosthesis leg to the "Wises"' 26052013

Furthermore while Radikal focuses on the solutions in its news such as:

"South East wants education right in mother tongue" 2105 2013; "Ensaroğlu: The problem of hate against Korucus (village guard serves to the Turkish Military) must be solved" 2504 2013;“"Wiseperson Uşşak: Calling names (for PKK leader) as 'baby murderer' is meaningless anymore" 04052013 ,

Sözcü focuses on victory rather than solving the problem:

(Citizens) Made life unbearable for 'wises' in Kayseri: Since citizens showed a great rebuff in their visit to Kayseri city, wisepeople committee of Central Anatolia had to run away from Kayseri city " 1804 2013;

"Rebuffs against 'Wisemen' are continuing: Rebuffs against 'wisemen' that are continuing for days all around the country also continued in Hatay and Denizli cities" 2004 2013; Rebuff to the 'Wises' in Black Sea Region"15 042013

\subsubsection{Framing the reaction and support}

In most of the headlines of Sözcü, Rebuffs and shock are the most used words to define the reactions of the people against activities of wisepeople. In using such emotional and exaggerated words to define reactions news frames peace process and the activities of the committee as unacceptable attempts by majority of people and refers antagonistic character of the conflict which means no support for peace process and the committee. ("First reactions to the wisepeople: List of wisepeople that was declared by Prime Ministry draw a rebuffs from various section of the society" 03 04 2013; "A rebuffs from an AKP (governing party) member to the wises" 1304 2013; "The question that shocked wisepeople" 1704 2013; "Another shock for Wises in Bandırma town" 2704 2013; "Reactions against 'wisepeople' is getting bigger" 1904 2013; "Big shock for the 'wisemen"' 1704 2013) Also using mostly the words of rebuffs and shock creates negative tone in headlines. Not only in headlines but also in content and context of the news in Sözcü are

${ }^{3}$ Fordetailedinfo on Peace/Warjournalism: Galtung, J. (2002) "PeaceJournalism-a challange", in KempfandLuostarinen (Eds), Journalismandthe New World Order, Vol.2:StudyingWarandthe Media, Göteborg: Nordicom, pp.259-72; Lynch, J andMcGoldrick A. (2005) PeaceJournalism, Gloucestershire: HawthornPress 
focused preclusion the dialog of parties and blocking the channels of dialog between parties in doing so news served to create opposition between parties.

However, Radikal frames the reactions as protests that are normal. "Tension in wisepeople 's meeting" 2605 2013, "YIlmaz Erdoğan: Being protested is normal" 1705 2013, "Wisepeople are protested in Balıkesir city" 0305 2013, "The Police offered water to the angry protesters" 0405 2013) And also public supportfor peace process and the committee is covered in the news of Radikal ("YIlmazErdogan: Support for peace is 110 \% percent" 1905 2013; Support for 'Peace' came out from the convention of Alaoute 1205 2013; "Support for resolution process from Diyarbakır Prison" 0305 2013; "Demirtaş: This time resolution process is different" 3004 2013)

\subsubsection{Framing and Defining the Wisepeople}

Name of the committee first introduced as 'Wisemen Committee' by Prime Minister Erdoğan, but importance of using gender sensitive language was pointed out and the name of the committee has changed as 'Wisepeople Committee'. Despite of all discussions and warnings, Sözcü newspaper insists to use the degrading names for the committee such as 'wises' or wiseman/men in doing so, Sözcü newspaper ridiculed the intelligence of the committee members and denied the existence of women members of the wisepeople committee. Moreover Sözcü Newspaper defined the wisepeople committee as greedy ("They were promoted to the seven stars hotel from five stars: Latest news from Prime Minister's wisepeople" 22052013 "Are wisepeople getting paid?" 1705 2013), coward (...the wisepeople committee of Central Anatolia had to run away from Kayseri city" 1804 2013), ridiculous("Wise cat" 2804 2013; "Empty hall for 'Wisemen's' meeting" 705 2013) and humiliates their effort and their selves as misleading ("Just a tent theatre (illusionary and cheap, banal show)" 0404 2013; "Is he 'wiseperson'?" 0504 2013; "Look what wiseperson is talking about!" 24042013

On the other hand Radikal used a gender sensitive and respected language about the wisepeople committee and made salient positive developments that is related to being member of the committee in such headlines:"They peaked (in media coverage) as a result of being chosen wisepersons" 30042013 and paid tribute them.Also headlines such as: "Wisepeople picked roses" 2105 2013; "Wisepeople danced in an Armenian village" 2104 2013; "Wisepeople participated to a wedding party, visited a marketplace" 1504 2013, portray the committee members ashumanist, respectedand peaceful individuals who has good relations with people and welcomed by people.

In contrast Sözcü portray wisepeople as disrespectful and against the Turkish national values like national anthem and flag ("As wises did not say the national anthem!: Wisepeople shocked by reaction of hall since they did not sing the national anthem" 1504 2013; "Intervention to the Turkish flag from "Wises" 2005 2013) and at least supporter of leader of PKKthat implies being terrorist ("Apo (leader of PKK) chooses the wisepeople" 1804 2013) Also headlines like "The Police rescued the "Wises'" 19042013 define wisepeople as if they are under attack of people who hate them.

Contrasted framing and portraying of two newspapers can be seen also in the headlines of the news related to a member of wisepeople. Lami Özgen is the president of Confederation of Public Sector Trade Unions which includes Union of Education that advocates the right of education in mother tongue for Kurds. Özgen was chosen as a member of the committee of wisepeople. Almost one month later he was front of the prosecutor to answer the acclaimed accusation that was being a member of the terror organization PKK. Coverage and the framing of two newspapers' show opposite directions of journalism practice. Whereas Sözcü demonize and criminalize Mr. Özgen who also represent more than 200000 union members, ("Wise turned out terrorist: President of Confederation of Public Sector Trade Unions Lami Özgen is prosecuted of being member of the terror organization " 0705 2013) Radikal emphasize the contradiction between governing bodies of the state that Mr. Özgen suffers by headlining that "According to government he is a wiseperson, according to the prosecutor he is a terrorist: President of Confederation of Public Sector Trade Union Lami Özgen will try to provethat 'he is not a member of terror organization'front of the judge" 06042013

\section{Conclusion}

In the light of these findings we can say that the media can employ both peace oriented discourse and war oriented discourse by framing the issues by using peace/conflict and human rights based journalism or war/violence based journalism. In any case the media plays a central role to escalate or reduce the conflicts and violence. But we should remember that "War journalism is driven by propaganda and manipulation and is therefore biased and distorted." (Galtung quoted in Gilboa, 2009: 101) This type of media outcomes polarize people, escalate conflict, otherize distinct group (s) of society as 'them' and dehumanize, demonize 'other' easily. As a result of it even if national or international human rights organizations try to give voice to the truth, people become deaf and blind just as the media is. Therefore the 
media workers should keep in mind that especially journalists, generally the media workers have social responsibility both for a better media and democracy. In order to fulfill that responsibility journalists should be aware the guidelines for peace reporting ${ }^{4}$ such as: (1) understand the conflict; (2) report fairly; (3) report the background and causes of the conflict; (4) present the human side;(5) report on peace efforts; (6) recognize journalists' influence. Last principle of the guidelines reminds responsibility of journalists on the ground of conscience: "We should always be aware that our reporting will affect the conflict and the lives of people in it"

The study concludes that the media can play an effective, positive role to prevent or reconcile ethnic conflicts and to contribute to the post conflict resolution, reconciliation and peace building. Harnessing the media for peace building saves the media from serving to the warmongers and keeps the media with peacemakers.

\section{Recourses}

Aydınlı, E and Özcan, N. A, (2011) The Conflict Resolution and counterterrorism Dilemma: Turkey Faces Its Kurdish Question, Terrorism and Political Violence, 23:3, 438-457

Bennet, C, How Yugoslavia's Destroyers Harnessed the Media, online at:

Bernard, P. E, (2009) Eliminationist Discourse in a Conflicted Society: Lessons for America from Africa, Marquette Law Review, 93, 173207

Davison, J. (2006) The Politics of Hate: Ultranationalist and Fundamentalist Tactics and Goals, Journal of Hate Studies, 5: 38

Entman, R.M. (1993). Framing: Toward a clarification of a fractured paradigm. Journal of Communication, 43 (4), 51-58.

Erdem, T. Türkiye ve İstanbul'daki Kürt Nüfusu, (Kurdish population in Turkey and Istanbul) Aktif Haber, 14 Nisan 2013 also available at: http://www.aktifhaber.com/turkiye-ve-istanbuldaki-kurt-nufusu-768705h.htm

Ethnicity, Demography, and Politics." Nationalism and Ethnic Politics 2004, Vol 10 pp. 473-504

Euwema, M and Verbeke, A, (2009)" Negative and Positive Roles of Media in the Belgian Conflict: A Model for De-escalation" Marquette Law Review, 93, 139-170

Gamson, W. and Modigliani, A. (1989)" Media discourse and public opinion on nuclear power: A constructionist approach." American Journal of Sociology, 95, 1-37.

Gilboa, E, (2009) Media and conflict Resolution: A Framework for Analysis, Marquette Law Review, 93, 87-110

Hackley, S. G, (2009) "In the Global Village, Can War Survive?" Marquette Law Review, 93, 25-42

Hamelink, C. J. (2008) "Media between warmongers and peacemakers", Media, War \& Conflict, 1:77

Hanitzsch, T. (2004) "Journalists as Peacekeeping Force? Peace journalism and mass communication theory", Journalism Studies, Vol. 5 (4), pp. 483-495

Holbrooke, R. cited from online at: http://www.historyplace.com/worldhistory/genocide/bosnia.htm

http://www.pbs.org/wgbh/pages/frontline/shows/karadzic/bosnia/media.html last visited 20 May 2013

Hrant Dink Foundation (Jan-Apr. 2011) Media Monitoring Report online at: www.hrantdink.org

Int'l Crim. Trib. For Rwanda trial Chamber I: Prosecuted v. Nahimana, Barayagwiza and Ngeze, (Media Case), (2004) Harvard Law Review, 117: 8, pp: 2769- 2776

Kalathil S, Langlois J and Kaplan A. (2008) Towards a new model: media and communication in post-conflict and fragile states. Available at: http://siteresources.worldbank.org/EXTGOVACC/Resources/CommGAPNewmodelWeb.pdf

La Brosse, R. (2003) Political Propaganda and the Plan to Create a "state for all Serbs": Consequences of Using Media for Ultra Nationalist Ends, Expert Report for International Tribunal For Yugoslavia

Laciner, S.and Bal, I. "The Ideological and Historical Roots of the Kurdist Movement in Turkey:

Laplante, L. J and Phenicie, K, (2009) Mediating Post-Conflict Dialogue: The Media's Role in Transitional Justice Processes, Marquette Law Review,93, 251-283

Loizides, N. (2009) Elite Framing and Conflict Transformation in Turkey, Parliamentary Affairs, 62: 2, 278-297

McDowall, D. (2000) A Modern History of theKurds, New York: I.B Tauris,

McLaughlin, G and Baker, S, (2010) The Propaganda of Peace: the Role of Media and Culture in Northern Ireland Peace Process, Bristol: Intellect Books.

McLaughlin, G and Baker, S, (2012) The Media, the Peace Dividend and 'Bread and Butter' Politics The political Quarterly, 83:2,292 298

Metzel, J F. (1997Nov-Dec) Information Intervention; When Switching Channels Isn't Enough: The Rise of Illiberal Democracy, Foreign Affairs, available at: www.columbia.edu/itc/sipa/56800/foreign_zakaria.pdf last visited 28 April 2013

Özkırımlı, U, (2013) Vigilance and Apprehension: Multiculturalism, Democracy, and the 'Kurdish Question' in Turkey, Middle East Critique, 22:1, 25-43

Pauly, J, (2009) Is Journalism Interested in Resolution, or Only in Conflict, Marquette Law Review, 93, 7-23

Reuben, R. C, (2009) the Impact of News Coverage on Conflict: Toward Greater Understanding, Marquette Law Review, 93, 45-83

4International Journalists' Network, Guidelines for peace reporting is available at http://ijnet.org/stories/guidelines-peace-reporting 
Saracoğlu, C, (2009) Exclusive recognition: the new dimensions of the question of ethnicity and nationalism in Turkey, Ethnic and Racial Studies, 32:4, 640-658

Schneider, A. K, (2009) International Media and Conflict Resolution: Making the Connection, Marquette Law Review, 93, 1-6

Somer, M and Liaras E, (2010) Turkey's New Kurdish Opening: Religious versus Secular Values, Middle East Policy, 17:2, 152-165

Somer, M, (2005) Resurgence and Remaking of Identity: Civil Beliefs, Domestic and External Dynamics, and the Turkish Mainstream Discourse on Kurds, Comparative Political Studies 38: 6, 591-622

Villellas, A, (2013) "New Peace Talks in Turkey: Opportunities and Challenges in Conflict Resolution", Insight Turkey, Vol. 15:2, p: 19-26 Yegen, M. (1999) "The Kurdish Question in Turkish State Discourse", Journal of Contemporary History, Vol.34 (4). 